\title{
A Healing Journey toward Oneself: Paul Ricoeur's Narrative Turn in the Hermeneutics of Education
}

\section{Andrew Wierciński (Lublin)}

\author{
Narrative Mode of Understanding: Education as the Bildung of Humanity of the Human Being
}

We all witness the inadequacy of pragmatic, approved short term solutions to complex problems of educational systems at different levels. It is predominantly the mentality of efficiency and efficacy, healing which primarily directs main attention to a practical question of ?what needs to be done? to achieve the best results in a possibly shortest time with a minimal personal, visit this social, and financial involvement. In an educational setting we have more and more of those who would advocate that the difficult questions and interrogations regarding the essential meaning of education should be silenced, or at best relegated to the purely private sphere of individual intellectual curiosity since they seem to be contra-productive tendencies slowing down the efficiency of academic progress. In fact, the whole system and individuals exercise censorship not only in the ideological realm of what needs to be learned but in the primordial horizon of being human. There is a fundamental question as to the meaning of education, which goes beyond intellectual self indulgence to satisfy one?s desires and wants and personal enjoyment of gathering mere excesses of information, and addresses the possible benefit toward the greater integrity of an individual human being and human society. A human person, who lives in society and shares with the community his or her self-understanding, naturally contributes to the increasing of self-understanding of society by working on his or her own personal development. In fact, it is this social context, in which we discover what does it mean to be a human being and by learning about our needs and wants we experience the needs and wants of others. Therefore, education is by its very nature an exercise in human solidarity by contributing to integral human development. The real goal of education is not to support false confidence in one?s own intellectual treasures toward optimally orchestrated self reliance and independence, which hugely contributes to the social perception of a well educated person as proud and arrogant. It is rather to help to discover the full spectrum of what does it mean to be a human being and how to live a good life in just institutions including all insecurities and weaknesses not by masking and covering them up but by humbling ourselves in the deepest sense of humility. We must always take into account the ontological dimension of being human, which is the foundation of the functional dimension of the person as educator and educated. What is suggested here is a shift of paradigms, from concentrating on managing existing educational systems to offering optimal education by digging deeply together to understand the question behind the efficacy of educational systems, looking for something more profound and essential in the effort to benefit individuals and society. It is a shift from viewing people as actual burdens and obstacles on the way to achieving best educational results to seeing people in their full integrity as the raison d??tre of any educational system, and as such as a vital part of the possible solution. What is extremely important is to see a person not only as a recipient and object of educational activity but likewise as a true and first agent of education, subjected to complex integrating dynamics. A true educational success is not just about celebrating advances in accumulating information, which, unfortunately, is the widespread contemporary translation of consumerism. We need to call for a reconciliation between living one?s life and education. Education cannot be seen as the necessary evil, which prevents especially young students from enjoying their life, merely to secure the mandatory qualifications for a future professional life. Education means living one?s life as one is discovering the ever growing personal potential for human integral development. Life and education are closely united and give one another reciprocal meaning. Personal life outside the formal educational setting belongs essentially to the entire process of education. Time outside of the formal schooling is not for evading everything related to learning, but is the blessing to learn differently by dedicating oneself to anything elevating the human mind and spirit.

A human being is always a teller of tales. We live surrounded by our stories and the stories of others, and from the very beginning of our existence we learn to see everything in and around us through these stories. Our relation to the world and to ourselves is historically and culturally mediated: ?Our existence cannot be separated from the stories that we tell of ourselves? (Ricoeur, 1991, p. 156). Living life looks like a play in which we all try to tell the story happening to us here and now. We can here critically address Sartre?s opposition between story telling and living. Our life means telling our story by retelling the story, which is the active and creative participation in the tradition that we are (Sartre, 1938, pp. 61?621). And this retelling is never the same, since in the event of understanding, understanding is ?always-understanding differently? (Immer-anders-

Verstehen)ㄴ (Gadamer, 2000, p. 297). Telling the story stresses the active individual interpretation in all constitution of meaning. Narration has its powerful cleansing potential in allowing things to show themselves as they are: In need of interpretation. Reinterpreting that which has been transmitted to us allows us to con-struct and re-construct our story on the way to our personal identity. This interpretive process discloses the emancipatory power of narratives. However, there is also a potential of covering up when telling a story, since everything that disturbs the dynamics of the story told can likely be masked and reorganized so as to fit into the expected order. But exactly learning to meet the unexpected, the strange, and the unfamiliar highlights the central role of narratives in constituting the identity of a human being. Encountering the unfamiliar and strange helps us to mature as human beings and discover that our self-understanding is in constant need of being reinterpreted. It can be seen as a powerful encouragement to con-struct our own narratives often against the prevailing social order by giving to our life structures different from those imposed on us by society. What is essential is to get sensitivity toward social conventions and established patterns not by overcoming the prejudices but by critically engaging them. This discloses the existential aspect of 
education which is concerned with carrying oneself through one?s life. It is a special kind of carrying, carrying with happiness, eu-phoria. It teaches one to situate oneself between different cultural horizons and different narratives in order to consciously shape one?s identity and life story in the ambivalent horizon of in-between. It is about an encouragement to reinterpret one?s life in a new light as this light shines upon one: A courage not to stagnate, but bravely confront whatever comes up in one?s life.

\section{Education As Getting the Imaginative Variations of Ourselves}

Living one?s life means to learn to deal with the uncertainties of existence, not in the Cartesian sense of methodological doubting, but by learning to deal with inhuman solitude which painfully discloses the truth that ?self-understanding always occurs through understanding something other than the self? (Gadamer, 2000, p. 97). Narration encourages questioning the homogeneity of a world view by positioning oneself in different horizons. The ambiguity and unforeseeability of the story we tell of ourselves surprises us at first as the storytellers. ${ }^{3}$ It discloses the fragmentary nature of reality captured in narration and serves as a powerful corrective against the illusion of the full intelligibility of the story told. But this provisional understanding is characteristic of the way we live our lives as lingual beings in the horizon of human temporality and facticity. The stories we tell of ourselves form the medium through which we interpret ourselves and the world we live in: ?There is no self-understanding that is not mediated by signs, symbols, and texts? (Ricoeur, 1981, p. 15). By constantly reinterpreting our narrative identity through the stories we tell, we realize that we are responsible for the way we live our lives. As responsible persons we understand our lives as an exercise in seeing differently, understanding differently, and acting responsibly.

In his detailed studies of textuality (Schriftlichkeit) Ricoeur tells us that it is only in the act of reading that the meaning of the text itself is actualized. Reading opens up new possibilities for our being-in-the-world. Particularly, the poetic discourse discloses the hidden aspects of reality by bringing them to language. This new way of seeing things allows for a new way of experiencing the world. 4 Therefore each reading, while disclosing some new aspects of reality, is a new way of inhabiting the world. This exercise in seeing and understanding sensitizes us toward dealing with the plurivocity of meaning, since the story told is narrated through the multiplicity of forms and the symphony of voices. What we need to deal with is often the confusion of voices, which calls for conflicting interpretations. The task is not to eliminate the difficult or even disturbing voices, but to carefully listen to each and every story.

Ricoeur (1983) reminds us that ?to understand oneself is to understand oneself as one confronts the text and to receive from it the conditions for a self other than that which first undertakes the reading? (p. 191). In the act of reading we are not predominantly searching for extra information about the matter of the text, but for a deepening of our self-understanding. This search for wisdom and not for a cumulation of punctual knowledge is based on paradox, which creates reflective equilibrium and situates human life, and particularly human freedom in the tension between dependence and independence, disguise and disclosure. The task of the hermeneutics of education is to encourage living this tension to one?s fullest potential in constant learning to understand one?s life story, which in everyday situation is re-told, each time somehow differently. Retelling one?s life story from the different perspective contributes to a new self-understanding. This truly transforms us by changing the meaning of our life. The literal Latin meaning of experience (ex-perire) invites us to get out, to go on a journey. With reference to education, this is a call to experiment with the different possibilities, going on an excursion both in the imaginary world and in reality. To get out of our own world and make ourselves on the journey helps us to make our own experience of the otherness of ourselves and otherness of the others and situates us between familiarity and strangeness. This empowers us to search for the meaning of our life by constantly reinterpreting that which needs to be understood.

\section{Education as the Narrative Event: The Unity of the Art of Story Telling and the Art of Living a Good Life}

Essential for the concept of education is the understanding of human being. A hermeneutics of education makes us aware of the transformation happening with and within us during the process of education. Education is far more than just a filling in of the gaps of knowledge with some useful information globally standardized and executed as the possession needed for the quality of human life. Two contradicting models of understanding serve here as the basic ground for differentiating attitudes toward understanding of education. In the rationalistic ideal, predominant in educational systems, human being is approximating the perfection of understanding. The critical student knows that he does not know, but the goal is to know completely. The painful experience of not rising to this ideal motivates a sincere effort to overcome the practical limitations, deficiencies, and inadequacies of a given educational system. The recognition of imperfect understanding is an experience of personal defeat, which calls for a more active effort to learn. This is a life in the horizon of hope to conquer, to be in charge, and to master oneself.

On the other hand, for the hermeneutic position, understanding is always incomplete, not because we are still lacking some information, but because we are finite human beings. The historicity of understanding and finitude of human existence are essential characteristics of being human. Incompleteness does not need to be experienced as personal defeat, but rather opens up a space for us to embrace ourselves as we truly are, human beings moving within a muted horizon. Muted means blurred, but also obscured, overshadowed, and silenced. It is truly a fusion of horizons. This moving within a horizon has a motivating character, in the sense of putting us as persons into motion (mo-vere), to be responsible for our own life-project, and keep our desire high to effectively execute it. 


\section{Education and the Art of Hospitality}

Education is definitely about fusion, which is also a con-fusion of voices (Ver-wirrung). The Book of Genesis tells us about the human desire for unity. The tower of Babel is a powerful critical metaphor for the quest for a common language, culture, and religion in answer to the danger of being scattered abroad upon the face of the whole earth. (Genesis 11: 4?8) However, God?s contempt for human pride as displayed in the intended competition with him and the subsequent dispersion of languages made it difficult or sometimes even impossible for people to understand one another. Therefore, education can be perceived as a powerful experience helping people to understand each other, which, in turn, can present somehow a real danger for a society if it wants to keep control over the individual person and group of people. Here the phenomenon of translation as a help to understand oneself and another comes into play, especially because of the close link between the task of translation and the nature of interpretation.

Ricoeur reminds us of the primordial need of translation. We always need to translate, both in the strict (interlingual) and broad sense, including the intralingual translation, ?synonymous with the interpretation of any meaningful whole within the same speech community? (Ricoeur, 2006, p. 11). Even our soliloquium is a con-versation with ourselves, a turning toward ourselves while translating the hidden and unknown into something familiar and known. Exactly in this in-between of familiarity and strangeness we address the presumption that what is said in one language cannot be said in another. Taking Ricoeur as our guide, we can locate ourselves in-between two fantasies: A ?fantasy nourished by the banal admission that the original will not be duplicated by another original? and a fantasy of a perfect translation (Ricoeur, 2006, p. 5). Translation has something to do with localization, with positioning oneself, with the inhabiting of a new territory. Hermeneutic translation happens in the horizon of symbolic imagination and is always, as Ricoeur (2006) says, a ?challenge and source of happiness? (p. 3). It makes the difficult or seemingly impossible possible with all necessary limitations. There are two paradigms of translation, for Ricoeur, the linguistic paradigm, which refers to the way words relate to meanings within language or between languages, and the ontological paradigm, addressing the relationship between translation and human being as oneself and another. In either case, translation calls for hospitality. Ricoeur says:

And it is this mourning for the absolute translation that produces the happiness associated with translating. The happiness associated with translating is a gain when, tied to the loss of the linguistic absolute, it acknowledges the difference between adequacy and equivalence, equivalence without adequacy. There is its happiness. When the translator acknowledges and assumes the irreducibility of the pair, the peculiar and the foreign, he finds his reward in the recognition of the impassable status of the dialogicality of the act of translating as the reasonable horizon of the desire to translate. In spite of the agonistics that make a drama of the translator?s task, he can find his happiness in what I would like to call linguistic hospitality. So its scheme is definitely that of a correspondence without adequacy. Fragile condition which accepts, in place of verification, only that work of retranslation ... understood as a sort of exercise in doubling the work of the translator through minimum bilingualism: retranslate after the translator. I took these two models, more or less comparable to the psychoanalysis of the work of memory and of the work of mourning, as my starting point, but I did so in order to say that, just as in the act of telling a story, we can translate differently, without hope of filling the gap between equivalence and total adequacy. Linguistic hospitality, then, where the pleasure of dwelling in the other?s language is balanced by the pleasure of receiving the foreign word at home, in one?s own welcoming house. (2006, p. 10)

Ricoeur eloquently pinpoints the drama of the translator?s task. However, with equal determination he calls for what he calls ?linguistic hospitality.? It is a clear opposition to any resignation and frustration associated with the impossible task of translation. On the contrary, we must translate. And there is no other way of improving what has been lost in translation so as to retranslate, to say it again, differently. There is no space for surrendering, but a dramatic existential call to yet another attempt to inhabit the world of the other as expressed in that which needs to be translated. This linguistic hospitality is a mode of lingual and dialogical dwelling in the world.

The encounter with the other, who speaks a different language, also discloses something essential about the educational task. Ricoeur encourages the hermeneutic approach to education by inviting a range of competing narrative possibilities. Our task is to thematize the formative process of those narratives in their productive tension, with a special emphasis on the ?capable subject? aiming at the ?good life? in ?the just institutions.? But education cannot be reduced to a mere function in a life of an individual and society. Since it is in essence a search for truth, while searching for one?s own personal identity, fostering an education means convincingly advocating for the development of the whole human person in their richness and diversity as they struggle to live a good life. There is a justified question regarding the insitutionalization of the concept of education with reference to its practical application for a concrete academic system. Our common effort is to work together by sharing our concerns for the wounded self in its journey toward identity. And it is a life in tension between the interest of the individual and the society, maybe even a conflict of interests, which definitely produces conflicting interpretations. It might be helpful to speak here of an unstable equilibrium, which is the result of negotiating those conflicting interpretations. What is required when confronted with a particular educational system is the active role of an agent, not a passive observer and recipient. Interpretive tension needs to be thematized and explored, not suppressed and overcome. Thus, a hermeneutic approach is a call for an imaginative involvement, an effort to phronetically engage the plurality of perspectives and not apply the rules in a purely technical way to the given educational situation. One of the problems with any educational system is that it enforces some order or pattern, which is likely to restrict the space for individual development. Therefore, it is crucially important to stress 
the provisional character of any educational system, which instead of being perceived as something ?fixed? is understood as creatively assisting a dynamic development of an individual and the society. In that context, the educational institution is perceived not as imposed by a social system, but as a gift. Not everything can be accomplished within the educational institution. The raison d??tre of the institution is to support the actualization of human development (Vollzug), for individually, without the presence of others, we would not be able to live up to our potential. If we understand education as a gift, we are more likely to accept the tension between the desire of an individual and the rule of the system. However, we need to be mindful of the internal human rebellion against the rule, which, throughout the course of history brought a lot of disgrace and far fewer blessings.

The Olympic ideas as expressed in the triad, citius, altius, fortius (faster, higher, stronger), beautifully capture the emphasis put on education. Unfortunately, the intensity of the life style as described by the determination of the one as expressed through three (?? ??? ?????) is often reduced to a selfish competition against the other, which is very much in contradiction with this noble ancient ideal. Similarly, introspection and inwardness, as much as they help us to reach our very potential, can prevent us from truly being present to others when we are so wrapped up with ourselves that our self-concern makes us inhospitable to foreigners and strangers, both in terms of people as well as other forms of life and ideas. Therefore, what is asked of us is hospitality perceived as a duty (originated in the biblical command to welcome the stranger) and as a gift. The Bible teaches us that hospitality, in essence, is the expression of the divine generosity and in the early history of human kind this was a pure necessity for a survival. It was a call to unconditionally welcome any guest and offer to the guest something exceptional beyond the ordinary experience within the confines of one?s own situatedness.

Genesis 18, 1?10 portrays Abraham as the generous and hospitable host. At the oaks of Mamre, the messengers of God are welcomed with opened arms by Abraham and Sarah. Sarah remains in the tent and prepares the feast for the guests. Although she does not enjoy their company, she enjoys the benefit of their promise: Nine months later she gives birth to her son, Isaac. Abraham and Sarah welcome the messengers as they welcome the message. The gift comes with the giver. The reception of the gift requires the welcoming of the giver.

In the New Testament, hospitality is described as ?philanthropia?, the love of fellow human beings, and kindness toward the other. A particular style of hospitality is demonstrated by the story of Martha and her sister Mary in Bethany (Luke 10, 38?42). I call it ?narrative hospitality,? since the deeper understanding of what it means to welcome your guest uncovers slowly with its own dynamics of the lived experience of friendship. Being caught up in the practical demands of everydayness ourselves, we might be tempted to read the story as the depiction of ?the one thing? that is needed to live a meaningful life. The biblical story is much more complex and provocative as a presentation of a generous practical hospitality versus an attentive spiritual reception of the other. It is not predominantly a question of shifting between two models of life and two versions of hospitality; it is not even about a balance between activity and passivity, calculation and meditation, business and leisure, but a total receptivity with undivided attention toward oneself and the other. What is extremely inspiring in this biblical story about the different manifestations of hospitality is the reinterpretation of the meaning of human action. It is not as much what we do that opens up the new horizon of meaning, but how receptive we are to the presence of the guest. This active attention to the stranger becomes the paradigm for a meaningful life. Maybe ?the one thing? which is mentioned in the biblical story is this unrestricted undivided attention: Living for the sake of the other while discovering always anew our personal identity as a task and a gift.

The essence of education is not to instruct or indoctrinate but to awaken a sensitivity and creativity. The experience of the work of art discloses something important about the educational task as motivated by the genuine desire to let the different artistic expressions work synergistically on the recipient. There is a mutuality between the work of art and the recipient, who is not just a passive receiving agent, but an active creator: What is happening is the transformation through art, which, in turn, creates art through transformation in the interplay of the mutual conditioning and enrichment. Without the participation and contribution of art many existential problems are insoluble. Art is an antidotum to the often bloodless academic dispute and as such a healing of the human mind in a passionate search for understanding. The educational undertaking is to support the person growing up by developing the individual potentiality, the passion for the possible, and to assist in the discovery of a personal identity, which is always open to interpretation. Ricoeur makes us aware that even the meaning of Being is not accessible immediately, but is always mediated through an endless process of interpretation. Narrative identity is the integration of the subject as same and the subject as self. Living our life means narrating our life story. We are the actors of our lives, living in the horizon of the possibility of a dynamic answer to the surprise of life. To be a human being is to make real the potentialities for existence, the very possibilities of our being-in-the-world.

Since we do exist in the context of narratives, what narratives we choose to hold onto as a guide (Wegweiser) is a complex question of our personal conviction, but also a challenging and enigmatic fate (Schicksal). Education is primarily about human beings, and about the art of dealing with human beings as the way to cultivate the culture of being with the other. In fact, the privileged way from oneself to oneself is through the other. Meeting the other is a question of fate. In the context of education we can speak of fate (the good fate) of a student meeting a good teacher, who is not a bloodless machine responsible for the transfer of information, not just a professional, who ?possesses? all the required expertise as a teacher, but a real human being. We do not need sedes sapientiae in the sense of a static place occupied by people who make education into a business of the transfer of knowledge. Calling for the rediscovery of the student as a human being, as an individual presupposes understanding of the student as a narrative, who, in turn, has or even is one?s own narrative in need of interpretation with the hospitality toward the conviction of the other. 
A good teacher is the phronimos, someone whom we love, need, but also someone whom we cannot stand, because we feel that he is somehow superior in dealing with the demands of everyday life. In the face of that person we see our own deficiencies, everything we do not like in ourselves, the need for real con-version of heart. It is often a real love-hate relationship. A teacher is not a dominant possessor of knowledge, but a phronimos. And here phronimos is not necessarily an individual person. We rather think here of the collective phronimos, a collective narrative identity with the paradigmatic desire directed to our selfrealization, to seeking fulfillment.

What is essential in education is the search for accordance and maybe even some form of reconciliation between the inner understanding of oneself, the interior of a human person with the external expression. It is a kind of trans-lation, for oneself and the other. It is a movement, like in a dance, an attempt to find an ex-pression of welcoming the arrival of the other, the strange, and the unexpected. Since we are the multiplicity of voices, creating a symphonic expression of who we are, this hermeneutic work is an expression of our hermeneutic hospitality, of welcoming the foreign not as a threat and potential danger but like a gift. But the gift is also a challenge, requesting from us the readiness to confront the unexpected. Our hospitable answer to the presence of the other, welcoming her/him does not have anything of the personal triumphalism. It is a hermeneutics in action, reminding us that to understand is always to be moving in-between, trans-locating, re-positioning ourselves to see the same from a different angle. Therefore, doing hermeneutics means interpreting life in all its inherent forms of expression, searching for the plausible account of oneself and the other in the imaginative and empathic loving struggle.

\section{Degenerated Art: Ricoeur and the Antitotalitarian Education}

In everyday life we are often confronted with different standards, we are told what is good, acceptable, beneficial for us. Growing up under the socially not just accepted but even welcomed pressure of those standards, we often realize that we are not in a position of fulfilling these expectations. Sometimes we even recognize that we do not want to fulfill them. Thematizing the very problem, which is happily diminished or even neglected by the society, we recognize that we need a healing journey toward ourselves, to face ourselves in our face however dis-formed. We need to learn to see who we are and try to understand why we are the way we are. This is the hermeneutic task of interpreting own our life as we live it.

Art helps us to do it. One of the venues is to use narration as a powerful tool. Narration in literature and narration in visual arts help us in searching for our narrative identity. The other is not always right in telling us what is best for us in terms of our individual and social life. ?Degenerated Art? (entartete Kunst) was during the time of National Socialism in Germany the term used to defame modern art. The exhibition ?Degenerated Art? on July 19, 1937 in the Hofgarten in Munich was originally planned as the didactic tremor (Erschütterung) to traumatize the spectators. However, the interest in the exhibition of mocked art (verspottete Kunst) significantly outnumbered the visitors of regular events. The idea of the parallel display of modern art with the pictures and drawings of the mentally handicapped and crippled people to cause disgust and anxiety among the visitors seemingly did not work. However, the absurdity of equating the avant-garde with sickness and degeneration legitimized the pursuit of eradication and annihilation of those who express themselves differently.

The political system defined that which was sick in the art. It was vital to determine what is healthy for the nation, in both a physical and moral sense. The German expression aus der Art schlagen can be simply understood as ?being totally different? (völlig anders sein). The term ?degeneration? (Entartung), especially in medicine, is the expression of the transformation of benign into malignant tumors. In fact, there is something particularly malign (bösartig) about being different. For any system, difference means endangerment, causing a reduced or even possible lost of control over the individual. Therefore, decay and deterioration (Verfall) and estrangement and alienation (Entfremdung) are the negative key concepts in any totalitarian Summa, in which particularity and difference are the arch-enemies of the predictability and stability. The potential for controversy is serious enough to motivate any dictatorship to eradicate the possibility of conflictual interpretation. Those in power often dream of captivating human mind, of symbolically, but also physically burning any expression of freedom (Nazis book burning in Berlin in May, 1933). Free expression of the human spirit endangers the uniformity of ideologization and needs to be expelled and expatriated (relegated, sold, or burnt).

\section{The Art and the Healing}

André Malraux? powerful account of the museum in terms of its colonization of the human imaginary still provokes us to ask for the possibility of the privileged locus of art. Museum Folkwang in Essen used to be one of the most important museums for modern art. The name Folkwang means in German the hall for the people. The concept of its director Ernst Gosebruch, since its opening in the new building in 1929, was to bring together different artistic expressions and put them in an active interaction among themselves and the visitors. When Paul Joseph Sachs, one of the co-founders of the Museum of Modern Art in New York, visited Essen in 1932, he spontaneously acclaimed this museum ?the most beautiful museum of the world.? After many tragic historic developments, the museum was reopened in 1960. The attempt to reconstruct was a truly hermeneutic endeavor, conscious of the Wirkungsgeschichte. The original idea of letting things show themselves as they are and see them in their artistic interplay means for us today something similar and yet significantly different. We do not believe in a simple reconstruction, even if with the preserved detailed documentation it could be technically possible to somehow ensure the formal repetition of the past collection. Here we look for an interpretation, like in a painting; we look for the artistic not the physical anatomy. A perfect example of that paradigm shift is a painting of the German expressionist Ernst Kirchner, ?Moderne 
Boh?me,? 1924. It was his attempt, in the spirit of expressionism, to investigate and depict the unconscious world as it presents itself in the dreams and not fully logically justified manifestations. Here once again we deal with the phenomenon of transgression. Dreaming does not exhibit the limit of artistic uncovering. Experiencing the borderline to the state of being awake encourages rather the quest for the repressed and the unconscious. Similar to the Heideggerian claim of basic phenomenology, art does not need to reproduce the visible but makes it visible. As in the now famous ?Moderne Boh?me? art does not intentionally distort that which wants to be seen, but it portraits it following the own internal artistic logic and the strong personal feelings of the painter. To recognize in the bohemian perception of life the real thirst for life and its meaning implies a serious confrontation with life as it presents itself. Why not follow an artist in his firm believe that a piece of carved furniture is different from the conventional depiction. If the function of a chair back is to support a body, why not to portray it as consisting of real human beings?

In fact, painting offers the colors and forms a chance to become themselves, to take on a life of its own (sich verselbstständigen), as in Kandinsky?s ?Improvisation 28? in the second version (1912). It is a true concert with colors, a powerful expression of the feeling for the color. And it develops into almost barbaric colors, allowing for the feeling to cry out, to come forth, like in Emil Nolde?s, ?The Life of Christ,? 1911/12. The artist does do his diligent homework, working through his religious experiences from the childhood in the sense of Freudian Durcharbeiten. It is again a powerful success story of dealing with the personal trauma.

Conflicting narratives about the human history call for a hermeneutic key to heal past wounds and allow for hope, for a chance to begin afresh. However, revisiting the past is the necessary step toward healing. Experiencing trauma in a personal life we can justly ask about the benefit of steering history in a new direction after protracted violence. For some, it might be a clear personalized hope. We remember those lines from Isaiah 53:5: ?But he was pierced for our transgressions, / he was crushed for our iniquities; / the punishment that brought us peace was upon him, /and by his wounds we are healed.? The suffering ebet Jahwe is the healing: In his wounds is our health. Our convalescence is a question of trust in the possibility of being healed, in the recovery, which comes upon in spiritual exercises of internal healing.

Ricoeur accompanies us in our task of dealing with memory and forgetting by making our present into a healing journey helping us to deal with the past. An essential part of this difficult healing process is the experience of forgiveness. For him, there is no politics of forgiveness, it is because love ?proves to be foreign to the world and, for this reason, not only apolitical but antipolitical? (Ricoeur, 2004, p. 488). Forgiveness is a tragic wisdom, ?an eschatology of the representation of the past. Forgiveness, if it has a sense, and if it exists, constitutes the horizon common to memory, history and forgetting. Always in retreat, this horizon slips away from my grasp. It makes forgiving difficult: not easy but not impossible. It places a seal of incompleteness on the entire enterprise? (p. 593).

The Germans have a great term to describe the process of coming to terms with the past, Vergangenheitsbewältigung. It situates us between remembering and forgetting, convincing us that without remembering there is no forgetting and no forgiving. Rather, it is a call to awaken to consciousness (zum Bewusstsein erwachen). Art is a great companion on the way to become awaken (Wach-werden). Art is a-wakening (Er-wachen). By learning the sensitivity and attention to our own past we experience internal healing. Therefore, the journey toward understanding oneself is a way of constantly rediscovering one?s selfidentity. The need for healing arises not from a theoretical deliberation, but is a discovery of an attentive life. It is an expression of solidarity. Facing the person in need, we recognize what this person needs. Not predominantly in terms of the practical need, but of the needed presence in that person?s life. The next step might be a concrete help in the particularity of a broken life. We remember the blind Bartimaeus, the son of Timaeus from Mark, 10. He did not hesitate to disturb Jesus and asked him for help. He wanted somebody to pay attention to him. And Jesus addressed exactly what he asked him to do.

The task of education is to help us to be prepared to give an answer to the question: What would you say if you were asked what it is you want? Are we ready to give such an answer? We can never exclude the possibility that we will really meet somebody filled with empathy, who would be willing to answer our most intimate wishes. Or perhaps just assist us with something more mundane. Education can help us to see the horizon of our healing, despite the clouds on that horizon. It encourages discovering the meaning of pardon on the way to make this horizon into the horizon of healing. If pardon is a healing of memory, then remembering is necessary to pardon with forgiveness, which is an experience of healing the past in order to make us whole again for the future: Completion in proximity to consummation, bringing the cross and the hope of rising again. Only in that perspective can we grasp the need for healing, and patiently learn to give words to our pain.

Paul Gauguin is a success story. Gauguin was one of the most innovative painters of the late nineteenth century, who transformed himself into a painter from a clerk in a bank. When in 1871 he started to paint as a hobby, he did not necessarily expect to get overcome by passion for painting. Eventually, this passion called him to leave behind his solid job as a banker, his wife, and his family. He did not follow the established rules. Not breaking those rules does not necessarily mean the profound deeper understanding of the importance of them. On the contrary, conformity is often felt as the privileged way to respond to the subtle sometimes even unconscious influences of individuals and society or to direct and overt social pressure. Conformity is also a way of behaving in the implied presence of others, even when being by oneself, which is usually an expression of the interiorization of the imposed rules and accepting them as one?s own. Any unwillingness to conform carries with it the very real risk of social rejection. This personal vulnerability stands in an obvious conflict with the social pressure for success in personal and public life. Gauguin did not surrender to that pressure. When we look at his ?Primitive tales? of 1902 (Contes Barbares), we 
can admire his search for identity and his courage in taking a risk of expressing differently, of experimenting with the whole spectrum of established patterns and rules.

And speaking of risk we cannot overlook the possible danger and pain with a strange sense of alienation as we struggle. In testifying to the changing perspectives, the capable agent realizes the need to learn to look at pain without repugnance. Learning to deal with pain through art seems to be a productive antidotum to the pharmacologization and medicalization of pain and the divinization of a healthy life style and food. In Folkwang, art offers a spiritual company at the table. On one big table is food for the human being without differentiating between body and soul. As food for the whole human person serve different sculptures of Auguste Rodin, George Minne, Aristide Maillol, Medardo Rosso, and Wilhelm Lehmbruck. Different forms and structures are joined together like real food. This symbolic alternative is an invitation to a journey into oneself, understanding the plurivocity of voices, mutual relationship, dependence, in-dependence, freedom of expression, not exposing oneself to the pressure of society and the widely celebrated glorification of one perfect form achieved more and more frequently with the scalpel of the plastic surgeon. This spiritual company is a factic protest against the tyranny of the artificially created aesthetic ideals, against the dictatorship of the other, against the usurpation of the right to tell what is only right and good for the individual.

\section{Limits and Limitedness: The Paradoxes of Life}

The meaning of walls which can be freely moved as in Folkwang brings us to the question of the limit. The feeling of walls can accommodate our needs, create the space, rearrange the space, like in a dance. Dealing with limits can be a powerful liberating experience, like in an Latin maxim: ?Non coerceri maximo, contineri minimo, divinum est,? ?Not to be confined by the greatest, yet to be contained by the smallest, is divine.?

Rainer Maria Rilke, Die Welt steht auf mit Euch

Jetzt wäre es Zeit dass Götter träten aus bewohnten Dingen

Und das sie jede Wand in meinem Haus umschlügen Neue Seite

Nur der Wind den solches Blatt im Wenden würfe reichte hin

Die Luft wie eine Scholle umzuschaufeln:

Ein neues Atemfeld

Oh Götter Götter!

Ihr oftgekommenen Schläfer in den Dingen

Die heiter aufstehn die sich an den Brunnen Die wir vermuten Hals und Antlitz waschen

Und die ihr Ausgeruhtsein leicht hinzutun $\mathrm{Zu}$ dem was voll scheint unserm vollen Leben

Noch einmal sei es euer Morgen Götter Wir wiederholen

Ihr allein seid Ursprung

Die Welt steht auf mit euch und Anfang glänzt
With You the World Arises

Now it is the time for gods to step forth

From inhabited things

And tear down every wall in my house

New page

Only the wind tossing such a leaf in turning

Could shovel the air like clod:

A fresh field of breath

Oh gods gods!

You who are the familiar and yet still asleep in things

Who serenely arise who at the well

Which we imagine wash your neck and face

And who gently add their restedness

To what seems complete to our whole lives

Once more let it be your morning gods

We keep repeating

You alone are the origin

With you the world arises and a new beginning gleams

On all the broken places of our failure ${ }^{5}$

An allen Bruchstellen unseres Misslingens

This is a very meaningful description of our human fate. As long as we live, we question the meaning of life, and give life meaning.

The gods enter into the real life of real people as the gods who return. The „now” of the opening line unmistakably situates us on the threshold between absence and presence. In fact, god?s absence is experienced as the preparation for their return: Absence is a mode of presence. It is an intense anticipation, which creates a space for gods to return, to become the ecstasy of presence. The saturated imagination envisions the return as the wind, which blows where it chooses. It is difficult not to sense the similarity with the Holy Spirit (Cf. John 3, 8).

This powerful expression ?now is the time? (jetzt wär es Zeit) can also be read as the eschatological time which in a mysterious way opens up the horizon of the future by relating the past to the present. This is also a special moment, which we can call the experience of the limit (Grenzerfahrung). For Rilke, it has been a difficult time of feeling sick at heart and in health. It is difficult to breathe. The air needs to be shoveled through to free the energy. The wind can bring the salvation. When only gods will step 
forth from the inhabited things. This turning point might explain the intensity and immediacy of the experience of the gods? return with an almost silent prayer ?once more let it be your morning gods,? followed by the respectful gesture of acknowledging their otherness. They can tear down the walls and we believe in it. Our faith generates hope that Anow is the time.? Absence is presence, which remains inaccessible yet is real.

The returning gods are by no means strangers. They come often and inhabit the earth. Particularly, they have their domicile in things. What is truly amazing is the poetic careful architecture. The return of gods is prepared by the imaginary of sleep, inactivity, and a gentle transgression from sleep into awakening with all the imponderabilia, but, on the other hand, extremely concrete, like washing the face and neck the very first thing in the morning. It is a powerful picture of the morning oblation, which reflects gods? salvific activity at the dawn, a true Götterdämmerung.

Things are inhabited (bewohnt) because they are familiar (vertraut). The main reason for the familiarity is the proximity of the divine. But at first something must be broken down. There are the walls. They need to be distorted. It is something powerfully violent and thuggish, something essentially disruptive. However, this unapologetic conviction destroys the more sincere hope for change. It can be seen as a paradigm shift from ?you must change your life? (Du mußt dein Leben ändern) into ?I want to change my life? (Ich will mein Leben ändern) or maybe even ?let my life will be changed? (mein Leben sei verändert).

For the architecture of life, this never ending study, there is definitely an important metaphor of a wall, which needs to be turned down. And in this upheaval and change (Um-bruch) the hope for the new beginning (ein Neuanfang) is included. How many times, we can ask rhetorically, can we hope for this fresh beginning? Seven times, or seventy seven, or seventy times seven (Mt $18,21 ? 22)$ ?

Rilke speaks clearly of the venture (Wagnis) for the fresh start. But this venture will be transformed into a powerful and effective adventure only if we preserve (Bewahrung) our initial relationship to the primordial source of our very being. Therefore, we are again at our limit: The limit of the walls around us, but also the limit to our imagination. Is there a limit to out thinking? Rilke envisions the well. This well might let us see the fresh washed neck and face of the gods. But it might reveal something utterly different from the expected. For now we do not see clearly: Rather, per speculum et in aenigmate. (1 Cor 13, 12) It is our speculation, which allows us to perceive the variety of different things, and marks the similar traits of the reflected images.

The gods are truly different. The condensed feelings regarding their return, even though they are not the complete strangers, are a sort of personal testimony to the fundamental difference, since ?you alone are the origin.? It needs to be repeated and acknowledged in the spirit of recognition of difference: ?Once more let it be your morning gods.? And we can only keep repeating that we know that we are different and yet live in between the human and the divine, knowing that understanding our human limitation is not a suppressive recognition of our human impotence but rather a mighty discovery of the powerful ties with gods, who sleep and awake as they please. This repetition brings us back to the primordial source, where we can see ourselves, and from there on start to work on the project of our life. This beginning shines like the morning dew. Does it resemble love, which is ?like a morning cloud, like the dew that goes early away?? (Hosea 6, 4) Or do we rather hope not for a presence that simply vanishes, but that presence even while not fully accessible, yet one which heals?

The beginning shines and we can position ourselves in the relationship to that beginning. We can think this beginning (das Denken dieses Anfangs) and transform this experience into the mode of thinking and the mode of living. This meditative path of thinking and living transforms our life into a recollection toward that which in itself cannot be neither fully intellectually grasped (das Unausdenkliche) or expressed (das Unaussagbare). Narration becomes then the mode of living our life, always in reference to this primordial ground (der ursprüngliche Grund) with the elaborated consciousness of all our failings and shortcomings. In fact, this primordial ground shines to us in those who share our life and this shining happens exactly in the broken places of our deficiencies and failures (an allen Bruchstellen unseres Misslingens). This gleaming of the beginning associated with the presence of gods and the others in our life carries an enormous potential of healing, of mending those broken places. It is a testimony to a powerful transformation by the shared presence, a miraculous mutuality, which reveals the surplus of possible integration and cure.

This healing process happens within the community of people struggling to live a good life. As Ricoeur reminds us, this struggle happens in the horizon of mutual approval based on the fundamental confidence in the unique and irreplaceable existence of each other. As he says, ?this mutual approbation expresses the shared assurance that each one makes regarding his or her powers and lack of powers, what I termed attestation in Soi-m?me comme un autre. What I expect from my close relations is that they approve of what I attest: that I am able to speak, act, recount, impute to myself the responsibility for my actions... In my turn, I include among my close relations those who disapprove of my actions, but not my existence? (Ricoeur, 2004, p. 1326). This fundamental approval of existence opens up a possibility for the testimony with all the tension between confidence and distrust, critique and conviction, suspicion and sympathy.

Czesław Miłosz, the late Polish Nobel Prize Laureate in Literature in 1980, reminds us that we can accomplish great things only as a community, like a poet who needs the community of other poets, a joint effort to allow that which wants to be seen to present itself in the creative tension of revealing and concealing. Only the common effort will open the horizon of hope to get the picture in its incompleteness yet as diverse and broad as possible. Only together we can successfully walk through life experiencing beauty which shines transforming our lives. 
Czesław Miłosz, Report

O Most High, you willed to create me a poet and now it is time for me to present a report.

My heart is full of gratitude though I got acquainted with the miseries of that profession.

By practicing it, we learn too much about the bizarre nature of man.

Who, every hour, every day and every year is possessed by selfdelusion.

A self-delusion when building sandcastles, collecting postage stamps, admiring oneself in a mirror.

Assigning oneself first place in sport, power, love, and the getting of money.

All the while on the very border, on the fragile border beyond which there is a province of mumblings and wails.

For in every one of us a mad rabbit thrashes and a wolf pack howls, so that we are afraid it will be heard by others.

Out of self-delusion comes poetry and poetry confesses to its flaw. Though only by remembering poems once written is their author able to see the whole shame of it.

And yet he cannot bear another poet nearby, if he suspects him of being better than himself and envies him every scrap of praise.

Ready not only to kill him but smash him and obliterate him from the surface of the earth.

So that he remains alone, magnanimous and kind toward his subjects, who chase after their small self-delusions.

How does it happen then that such low beginnings lead to the splendor of the word?

I gathered books of poets from various countries, now I sit reading them and am astonished.

It is sweet to think that I was a companion in an expedition that never ceases, though centuries pass away.

An expedition not in search of the golden fleece of a perfect form but as necessary as love.

Under the compulsion of the desire for the essence of the oak, of the mountain peak, of the wasp and of the flower of nasturtium.

So that they last, and confirm our hymnic song against death. And our tender thought about all who lived, strived, and never succeeded in naming.

For to exist on the earth is beyond any power to name. Fraternally, we help each other, forgetting our grievances, translating each other into other tongues, members, indeed, of a wandering crew. 
How then could I not be grateful, if early I was called and the incomprehensible contradiction has not diminished my wonder?

At every sunrise I renounce the doubts of night and greet the new day of a most precious delusion.

From Facing the River (1995). Tr. by Cz. Miłosz \& R. Hass.

What is amazing in this witness of poetry is also the source of amazement in real life. The very meaning of interpretive task is to imagine a world possibly unfolding by the text. Poetic imagination creates the world in front of us, inhabits the space in front of the text. This unfolding creates the possibility of new meanings and represents a new internal architecture unique to the individual mode of life.

Knowing much about the dark side of human existence, a poet feels responsible for one?s vocation, which he believes is a call from God, a true gift from God. As Miłosz says, ?early we receive a call, yet it remains incomprehensible, and only late do we discover how obedient we were.? (Capri) This discovery of our identity happens in the course of our life, which, as such, is ?a most precious delusion.? It happens in a company of our fellow human beings, ?all who lived, strived, and never succeeded in naming,? with whom we share the responsibility for disclosing who we really are, even though, as in case of someone we consider superior to ourselves we are ?ready not only to kill him but smash him and obliterate him from the surface of the earth.? Poetry is the powerful disclosure: ?Out of self delusion comes poetry and poetry confesses to its flaw.? And even if neither the individual poet nor the company of poets will be able to ?succeed in naming,? since ?to exist on the earth is beyond any power to name,? (Report) poetry is probably the closest thing which allows for, however imperfect, communication between the living and the dead trying to find the meaning of Asomething among men, children, and women, something that cannot be defined, Aneither happiness nor unhappiness? (Throughout Our Land). In sum, the narrative imagination is the greatest gift we are offered here on earth. The task of education is to help us to understand that education is self-education in a permanent quest for ourselves, which situates us between attainability and unattainability, and despite all our likes and dislikes of others searching fraternally for a language in which ?the rhythm of the body will be in it, heartbeat, pulse sweating, menstrual flow, the gluiness of sperm, the squatting position at urinating, the movements of the intestines, together with the sublime needs of the spirit, and our duality will find its form in it, without renouncing one zone or the other.?z (Miłosz, 1986, p. 33).

Humility in Rilke to wait for gods? return and in Miłosz? persistence to remain astonished at the never-exhausted abundance of phenomena is an expression of understanding the connection with the source, with the beginning. Humility (humilitas) connects us with the earth (humus) to make sure that we have a solid grounding in life. It also helps to see the light which enlightens the darkness. And this light comes from the beginning. And shines through all the broken places. Failing to accomplish does not need to call for the final resignation, it is not a simple dis-couragement (Ent-mutigung). This poetic imperative situates us between the ever changing ?I,? and calls for the courage to start afresh, to try again, to make yet another attempt, even against all apparent signs of failure.

Similarly to the radical implication that there is no uniquely right way to say anything or translate anything, we can say that there is no uniquely right notion of education. Rather, it is an invitation to think always anew about the essence of education. The claim about being able to say the same thing in different ways results in our understanding of being finites: ?For want of a full description, we have only points of view, perspectives, partial visions of the world. That is why we have never ceased making ourselves clear, making ourselves clear with words and sentences, making ourselves clear to others who do not see things from the same angle as we do? (Ricoeur, 2006, p. 27). This hermeneutic view has a powerful implication for education. It means that instead of searching for the illusory perfect and efficient notion of education, we need to welcome the variety of ways we reach a deeper self-understanding and promote the culture of hospitality and attentiveness. If a human being with one?s unique capability and vulnerability is ?the Joy of Yes in the sadness of the finite? (Fallible Man), the hermeneutic task of education might be like this healing journey in the horizon of hospitality, no less and no more than the acceptance of our incompleteness.

\section{References:}

Gadamer, H.-G. (1993). Hermeneutik II: Wahrheit und Methode. Ergänzungen. Register.Gesammelte Werke, Bd. 2. Tübingen: Mohr.

Gadamer, H.-G. (2000). Truth and Method. Tr. by J. Weinsheimer \& D.G. Marshall, 2nd rev. ed. New York: Continuum.

Miłosz, Cz. (1986). Unattainable Earth. Tr. by Cz. Miłosz \& R. Hass. New York Ecco Press.

Ricoeur, P. (1991). From Text to Action. Essays in Hermeneutics II. Tr. by K. Blamey \& J. B. Thompson. Evanston, Illinois: Northwestern University Press.

Ricoeur, P. (1981). L?histoire comme récit et comme pratique . Ésprit (54), pp. 155?165. 
Ricoeur, P. (2004). Memory, History, Forgetting. Tr. by K. Blamey \& D. Pellauer. Chicago: University of Chicago Press.

Ricoeur, P. (1983). On Interpretation. In: A. Montefiore (ed.), Philosophy in France Today. Cambridge: Cambridge University Press.

Ricoeur, P. (2006). On Translation. Tr. by E. Brennan, introduction by R. Kearney. New York: Routledge.

Sartre, J.-P. (1938). La Nausée. Paris: Gallimard.

1. ?C?est ce qui dupe les gens: un homme, c?est toujours un conteur d?histoires, il vit entouré de ses histoires et des histoires d?autrui, il voit tout ce qui lui arrive ? traverse elles; et il cherche ? vivre sa vie comme s?il la racontait. Mais il faut choisir: vivre ou raconter.? (context)

2. ?Not just occasionally but always, the meaning of a text goes beyond its author. That is why understanding is not merely a reproductive but always a productive activity as well. Perhaps it is not correct to refer to this productive element in understanding as ?better understanding.? For this phrase is, as we have shown, a principle of criticism taken from the Enlightenment and revised on the basis of the aesthetics of genius. Understanding is not, in fact, understanding better, either in the sense of superior knowledge of the subject because of clearer ideas or in the sense of fundamental superiority of conscious over unconscious production. It is enough to say that we understand in a different way, if we understand at all? (p. 297). In the Introduction, ?Zur Einführung: Zwischen Phänomenologie und Dialektik ? Versuch einer Selbstkritik?, Gadamer (1993) emphasizes that hermeneutically speaking understanding means understanding always differently: ?Die Reflexion des hermeneutischen Bewußtseins auch anerkennt, daß Verstehen Immer anders Verstehen ist? (p. 8). (context)

3. Like in the etymology of Vor-trag, to carry something in front of oneself or in a sermon, when one preaches first to oneself. (context)

4. Even if the educational and transformative aspects of literature are hugely contested by our contemporaries, they can not be simply dismissed from the academic and public discourse. Miłosz critically questions this attitude while opening the horizon of possibility that there might be something wrong with us, as he says in his Unattainable Earth: ?Of course literature should be edifying. Whoever, because of an exceptionally avid imagination, succumbed to the bad influence of books, cannot think otherwise. The word ?edifying? is pronounced sarcastically today and that is sufficient proof that something is wrong with us. What great works of literature were not edifying? Homer perhaps? Or The Divine Comedy? Or Don Quixote? Or Leaves of Grass?? (Miłosz, 1986, p. 38). (context)

5. Translation mine. (context)

6. Ricoeur?s disapproval of person?s actions, but not one?s existence, reminds of the maxim, ?hate the sin love the sinner.? (

7. A few lines earlier Miłosz beautifully captures the sense of this constant search for a ?more spacious form? to ex-press who we really are: ?Since my youth I have tried to capture in words a reality such as I contemplated walking the streets of a human city and I have never succeeded; that is why each of my poems seems to me the token of an unaccomplished oeuvre. I learned early that language does not adhere to what we really are, that we move in a big make-believe which is maintained by books and pages of newsprint. And every one of my efforts to say something real ended the same way, by my being driven back to the enclosure of form, as if I were a sheep straying from the flock.? (Miłosz, 1986: p. 32.) (context) 